Research article

\title{
CONCENTRATIONS OF BONE MORPHOGENETIC PROTEIN-15 (BMP-15) AND GROWTH DIFFERENTIATION FACTOR-9 (GDF-9) IN FOLLICULAR CYSTS, MONO - AND POLYOOCYTE FOLLICLES IN GILTS
}

\author{
STANKIEWICZ Tomasz*, BEASZCZYK Barbara
}

West Pomeranian University of Technology, Szczecin, Faculty of Biotechnology and Animal Breeding, Department of Animal Reproduction Biotechnology and Environmental Hygiene, 6 Doktora Judyma Street, 71-466 Szczecin, Poland

(Received 24 December 2013; Accepted 14 January 2014)

The objective of the study was to determine the concentration of BMP-15 and GDF-9 in the fluid of follicular cysts and ovarian follicles, and to compare their concentrations in mono- and polyoocyte follicles in gilts. The study involved two experiments conducted on the ovaries collected post-slaughter from gilts (7-8 months old). The first experiment covered 31 follicular single cyst gilts $(15-25 \mathrm{~mm}$ in diameter) and 41 gilts without cysts. Follicular fluid from follicles of $8-10 \mathrm{~mm}$ in diameter $(\mathrm{n}=41)$ and $5-8 \mathrm{~mm}$ in diameter $(n=41)$, and cystic fluid $(n=31)$ were collected for analysis. The second experiment involved collecting follicular fluid from poly- $(n=19)$ and monooocyte $(n=22)$ follicles. The concentration of BMP-15 and GDF-9 was then determined in the samples using specimen-specific ELISA kits. The differences in the concentration of these factors were calculated by means of analysis of variance and a posthoc test. Duncan's multiple range test was used to verify the significance of differences at $\mathrm{P}<0.05$ and $\mathrm{P}<0.01$. In addition, correlations between the factors were calculated. BMP-15 and GDF-9 levels in the cystic fluid were significantly higher than those in the follicular fluid $(\mathrm{P}<0.01)$. However, no differences were observed between various size follicles or between mono- and polyoocyte follicles. BMP-15 and GDF-9 concentrations were found to be positively correlated $(\mathrm{P}<0.01)$. Differences in BMP-15 and GDF-9 concentrations in ovarian follicles and follicular cysts, as evidenced by our study, indicate that these factors may be related to folliculogenesis disorders in gilts. What is more, the number of oocytes in ovarian follicles does not influence the intrafollicular concentration of BMP-15 and GDF-9.

Key words: ovarian cysts, polyoocyte follicles, BMP-15, GDF-9, ELISA, gilts

\section{INTRODUCTION}

Many studies involving ovarian follicle functions have focused on the role of factors which are a part of the transforming growth factor beta (TGF- $\beta$ ) superfamily [13]. Amongst them, the bone morphogenetic protein-15 (BMP-15) and the growth differentiation factor-9 (GDF-9) deserve particular attention, as they participate in signalling pathways which control the development of ovarian follicles [3]. Recent

\footnotetext{
${ }^{*}$ Corresponding author: e-mail: tomasz.stankiewicz@zut.edu.pl
} 
research suggests that the factors affect the proliferation and differentiation of follicular somatic cells, steroidogenesis, deposition of the extracellular matrix, ovulation, and luteinization $[2,4,5]$. At the pre-ovulatory stage, the factors have an effect on oocyte maturation and cumulus cell expansion [6,7]. It is known that as a result of maturation, the oocyte gains developmental competence, which preconditions regular fertilization and subsequent embryo growth [8]. It is believed that BMP-15 and GDF-9 participate in the hormonal regulation of the hypothalamus-pituary gland-ovary axis [9]. Some suggest that the described factors may intensify or weaken gonadotropin impact on the ovarian follicle, depending on the stage of folliculogenesis. They affect LH receptor expression in the ovarian follicle somatic cells. It may play a role in the case of ovarian follicular cysts, which might be a result of LH deficiency [10,11]. Ovarian cysts are a major issue, which upsets pig fertility, in sows and gilts alike [11-14].

Cystic ovaries in pigs may be unilateral or bilateral; whereas the cysts themselves are either single or multiple [10]. In most cases, single ovarian cysts have no impact on pig fertility, but they do have the potential to become multiple ovarian cysts, which can affect fertility in females [14]. It is thought that the direct reason for ovarian cyst formation are hormonal disorders [15]. Thus, considering the involvement of BMP-15 and GDF-9 in hormonal regulation of the ovarian follicle, one may not rule out the possibility that these factors play a part in ovarian cyst pathogenesis.

Research into the role of BMP-15 and GDF-9 in the ovarian follicle prove that the mentioned factors are secreted mainly by oocytes. The majority of ovarian follicles contains only one oocyte; however, in some mammal species, there are follicles containing a higher number of oocytes [16-18]. The presence of polyoocyte follicles has been recorded, amongst others, in the ovaries of the pig [18]. Determining BMP-15 and GDF-9 concentrations in polyoocyte follicle fluid perhaps may indirectly indicate the level of oocyte secretion activity in the follicles, especially as there has been no explicit common standpoint regarding the quality of such oocytes.

Therefore, the aim of this study was to determine the concentration of BMP-15 and GDF-9 in follicular cyst and ovarian follicle fluid, and to compare the concentrations of the said factors in mono- and polyoocyte follicles in gilts.

\section{MATERIAL AND METHODS}

Two experiments involving gilts (7-8 months old), slaughtered in the local slaughterhouse, were performed as part of the research.

\section{Experiment No. 1}

The experiment was conducted to compare BMP-15 and GDF-9 concentrations in follicular cysts and ovarian follicle fluid. The analysis covered 31 gilts, in which follicular cysts were found, and 41 gilts without cysts. All follicular cysts, from which the fluid was collected, were single, unilateral structures filled with some light, clear liquid, and a diameter range of $15-25 \mathrm{~mm}$. A selected image of a single cyst in the ovary of a gilt is shown in Figure 1. 


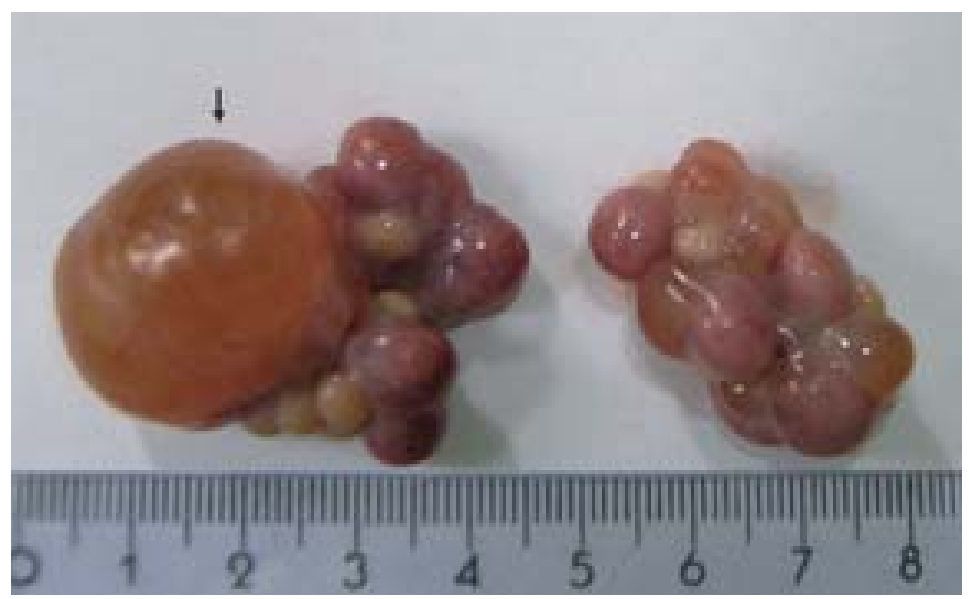

Figure 1. Macroscopic picture of a single cyst in ovary of gilts

In the remaining gilts, one ovary was selected from which to collect follicular fluid from an $8-10 \mathrm{~mm}$ follicle $(\mathrm{n}=41)$ and a $5-8 \mathrm{~mm}$ follicle $(\mathrm{n}=41)$. Ovarian follicles were well-vascularised and had a shiny surface according to Paradis et al. [7] and Hunter et al. [19]. Both cystic and follicular fluid was aspired with the application of a needle and a syringe, and subsequently centrifuged (500 $\mathrm{g}$ for $10 \mathrm{minutes}$ ), decanted and stored at a temperature of $-20^{\circ} \mathrm{C}$ until analysis.

\section{Experiment No. 2}

Experiment no. 2 was carried out to compare the intrafollicular concentration of BMP15 and GDF-9 between follicles classified according to the number oocytes. Follicular fluid was aspired from same-sized follicles (7-10 $\mathrm{mm}$ in diameter). To determine the number of oocytes, follicular fluid was aspired with the use of a separate syringe with a fitted needle, and then transferred into individual wells, according to the method by Stankiewicz et al. [18]. In order to minimise errors related to the possibility of oocyte loss, after each aspiration of a single follicle the syringe was rinsed out several time and its contents were transferred to another well. The content was evaluated in both wells. Moreover, the needle was used to gently scratch the follicular wall during aspiration. As described by Fouladi-Nashta et al. [20] this technique can be helpful in isolating oocytes from follicular wall compartments.

After calculation of the number oocytes under the stereomicroscope, the follicular fluid samples, both the polyoocyte $(n=19)$ and monooocyte $(n=22)$ follicles, were centrifuged, separated and stored at $-20^{\circ} \mathrm{C}$ until analysis.

\section{BMP-15 and GDF-9 assay}

With the application of specimen-specific kits, the BMP-15 (Porcine BMP-15 ELISA kit, Novateinbio Biosciences, Cat. No. POR10362) and GDF-9 (Porcine GDF-9 ELISA kit, Novateinbio Biosciences, Cat. No. BG-POR11087) concentrations were determined 
in the collected samples. Test sensitivity for BMP-15 was $0.1 \mathrm{ng} / \mathrm{ml}$, and in the case of GDF-9 - $0.1 \mathrm{pg} / \mathrm{ml}$. The intra- and inter-assay coefficients of variation were $<10 \%$ for BMP-15 and GDF-9. The measurement was conducted using the Wallac fluorometer 1420 VICTOR $^{2}$ (Wallac Oy, Turku, Finland). All assays were carried out in duplicate.

\section{Statistical analysis}

The obtained results were further submitted for statistical analysis. The resulting data are presented as the mean \pm SEM, marked on the graph, and tabulated. The differences in the concentration of the studied factors were calculated by analysis of variance and the posthoc test. Duncan's multiple range test was used to verify the significance of differences at $\mathrm{P}<0.05$ and $\mathrm{P}<0.01$. In addition, correlations between the studied factors were calculated with the Spearman rank correlation coefficient. Statistical analysis was conducted using the STATISTICA version 7.1, Stat Soft, Poland.

\section{RESULTS}

Mean BMP-15 concentration in the fluid of follicles with a diameter of $8-10 \mathrm{~mm}$ $(\mathrm{n}=41)$ was $0.63 \pm 0.02 \mathrm{ng} / \mathrm{ml}$, and it was higher than in follicles with a diameter $<8$ $\mathrm{mm}(0.53 \pm 0.02 \mathrm{ng} / \mathrm{ml})$. Nevertheless, the differences between the groups were not statistically significant (Fig. 2). Whereas, the concentration of BMP-15 in ovarian cysts was significantly higher than in both groups of ovarian follicles, and was determined as $3.02 \pm 0.52 \mathrm{pg} / \mathrm{ml}$ (Fig. 2).

As presented in Figure 3, differences in GDF-9 concentrations were distributed similarly. The concentration of GDF-9 in cysts $(12.17 \pm 0.89 \mathrm{pg} / \mathrm{ml})$ was significantly higher than in follicles with a diameter of $8-11 \mathrm{~mm}(3.80 \pm 0.04 \mathrm{pg} / \mathrm{ml})$ and in follicles with a diameter of $5-8 \mathrm{~mm}(3.46 \pm 0.08 \mathrm{pg} / \mathrm{ml}$ ) (Fig. 3).

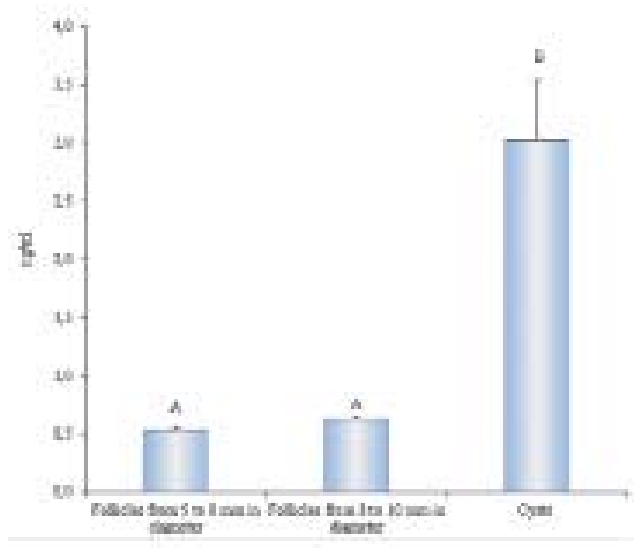

Figure 2. BMP-15 concentration in the ovarian follicular fluid and cystic fluid in gilts. Values are mean \pm SEM. A - mean values marked with various letter differ at $\mathrm{p}<0.01$

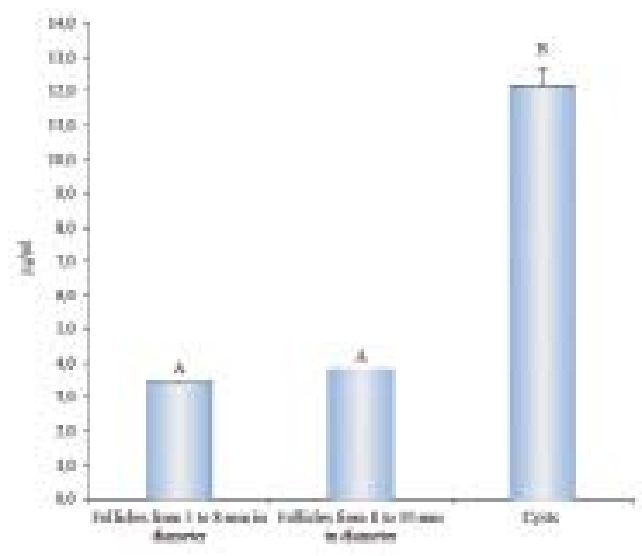

Figure 3. GDF-9 concentration in the ovarian follicular fluid and cystic fluid in gilts. Values are mean \pm SEM. A - mean values marked with various letter differ at $\mathrm{p}<0.01$ 
On the another hand, no statistically significant differences were observed between concentrations of the examined factors in the mono- and polyoocytes follicle fluid (Table 1).

Table 1. The mean ( \pm SEM) concentrations of BMP-15 and GDF-9 in follicular fluid classified according to number of oocytes in follicles

\begin{tabular}{lcc}
\hline \multirow{2}{*}{ Factor } & \multicolumn{2}{c}{ Follicles } \\
\cline { 2 - 3 } & Monoovular $(\mathrm{n}=22)$ & Polyovular $(\mathrm{n}=19)$ \\
\hline BMP-15 $(\mathrm{ng} / \mathrm{ml})$ & $0.667 \pm 0.024$ & $0.672 \pm 0.025$ \\
\hline GDF-9 $(\mathrm{pg} / \mathrm{ml})$ & $3.769 \pm 0.067$ & $3.801 \pm 0.066$ \\
\hline
\end{tabular}

The BMP-15 and GDF-9 concentrations were found to be positively correlated $(\mathrm{r}=0.69$; $\mathrm{P}<0.01)$, with the most pronounced correlation observed in the fluid of ovarian cysts (Fig. 4).

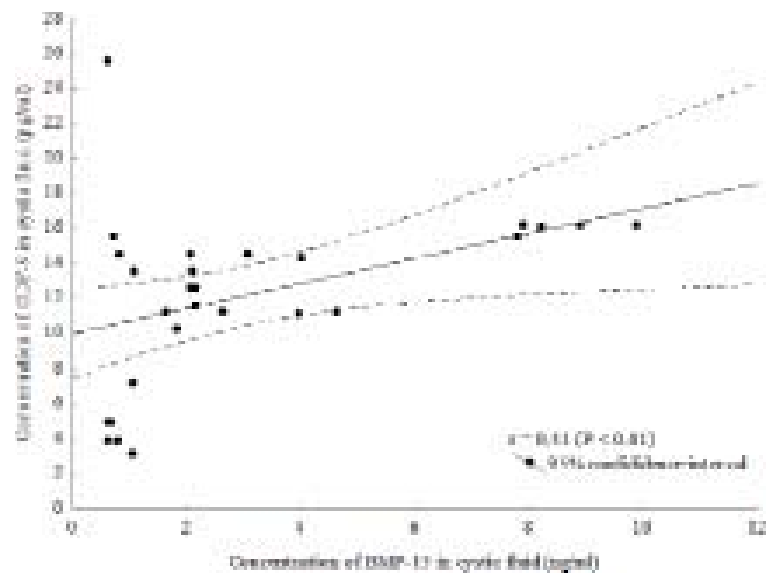

Figure 4. Correlation between BMP-15 and GDF-9 concentration in the cystic fluid of the ovaries in gilts $(\mathrm{n}=31)$

\section{DISCUSSION}

Until recently, an oocyte in a developing follicle had been perceived as a passive structure, having no effect on the ovarian follicle development. However, it has been shown that the communication between an oocyte and follicular somatic cells is bidirectional, and the oocyte itself is capable of secretion [21]. Amongst factors secreted by oocytes are BMP-15 and GDF-9. Current research focuses on the interrelation between an oocyte and follicular somatic cells [2-5,22]. The positive correlation between BMP-15 and GDF-9 demonstrated herein confirms a synergistic activity of the aforementioned factors [1,6]. This study demonstrates the presence of BMP-15 and GDF-9 in the ovulatory follicular fluid of gilts, which proves the fact that they are components of the follicular microenvironment $[2,4,23]$. However, BMP-15 and GDF-9 concentrations in 
follicular cysts were significantly higher than those in the ovarian follicles. Such high concentrations in the cysts might have been a consequence of BMP-15 and GDF-9 synthesis via somatic cells.It has been demonstrated that the expression of GDF-9 mRNA in pigs occurs not only in oocytes but also in the granulosa cells [23]. Thus, it cannot rule out intercellular interaction disorders, which may result in high levels of BMP-15 and GDF-9. Sun et al. [24] indicates that BMP-15 and GDF-9 affect the balance between follicular cell proliferation and apoptosis. This balance disturbance is in turn one of the reasons of ovarian cyst formation [25]. Namely, the transition of the follicle from the preantral to early antral stage is the "penultimate" stage of development in terms of gonadotropin dependence and follicle destiny [growth versus atresia] [26]. Follicles selected for further development are thought to receive precise gonadotropic and intra-ovarian regulatory signals for survival, whereas follicular atresia is a consequence of inadequate growth support [27]. Since ovarian dysfunctions are the consequence of this transitional stage-specific dysregulated follicle growth, understanding the molecular and cellular mechanisms in the control of follicular development during the preantral early antral transition may provide important insight into the pathophysiology of these conditions [28].

Another possible relation between BMP-15 and GDF-9 and cysts is demonstrated by their influence on the change in the direction of steroidogenesis. GDF-9 in rat intensifies androgen synthesis via theca cells of the ovarian follicle [32]. However, as Pache et al. [30] described, androgens play an important role in the genesis of ovarian cysts. Furthermore, BMP-15 and GDF-9 gene mutations impact fertility and ovulation [31-33].

As the main source of BMP-15 and GDF-9 in the ovarian follicle are oocytes, the present study comprises an additional analysis of the concentration of these factors in the fluid of mono- and polyoocyte follicles. One might have presumed that an increased oocyte count in the follicle would lead to higher concentration of both factors in the follicular fluid. However, the concentration of BMP-15 and GDF-9 in polyoocyte follicles was only slightly higher than in the monooocyte ones. This might be the result of a diversified secretory activity of oocytes from polyooocyte follicles. This suggestion found its confirmation in the studies conducted by Stankiewicz et al. [18], who demonstrated the varied quality of oocytes from polyoocyte follicles. On the other hand, regardless of the number of oocytes and their secretory activity within a follicle, there might be mechanisms responsible for the maintenance of an optimal BMP-15 and GDF-9 concentration to provide for folliculogenesis.

\section{CONCLUSIONS}

Differences in BMP-15 and GDF-9 concentrations in ovarian follicles and follicular cysts, as evidenced by our study, indicate that these factors may be related to folliculogenesis disorders in gilts. What is more, the number of oocytes in ovarian follicles does not influence the intrafollicular concentration of BMP-15 and GDF-9. 


\section{REFERENCES}

1. Knight PG, Glister C: TGF- $\beta$ superfamily members and ovarian follicle development. Reproduction 2006, 132: 191-206.

2. Su YQ, Sugiura K, Wigglesworth K, O’Brien MJ, Affourtit JP, Pangas SA, Matzuk MM, Eppig JJ: Oocyte regulation of metabolic cooperativity between mouse cumulus cells and oocytes: BMP-15 and GDF-9 control cholesterol biosynthesis in cumulus cells. Development 2008, 135: 111-121.

3. Sun RZ, Lei L, Cheng L, Jin ZF, Zu SJ, Shan ZY, Wang ZD, Zhang JX, Liu ZH: Expression of GDF-9, BMP-15 and their receptors in mammalian ovary follicles. J Mol Hist 2010, 41: 325-332.

4. Orisaka M, Jiang JY, Orisaka S, Kotsuji F, Tsang BK: Growth differentiation factor 9 promotes rat preantral follicle growth by up-regulating follicular androgen biosynthesis. Endocrinology 2009, 150: 2740-2748.

5. Peng X, Yang M, Wang L, Tong C, Guo Z: In vitro culture of sheep lamb ovarian cortical tissue in a sequential culture medium. J Assist Reprod Genet 2010, 27: 247-257.

6. Su YQ, Wu X, O’Brien MJ, Pendola FL, Denegre JN, Matzuk MM Eppig JJ: Synergistic roles of BMP15 and GDF9 in the development and function of the oocyte-cumulus cell complex in mice: genetic evidence for an oocyte-granulosa cell regulatory loop. Dev Biol 2004, 27: 64-73.

7. Paradis F, Novak S, Murdoch GK, Dyck MK, Dixon WT, Foxcroft GR: Temporal regulation of BMP2, BMP6, BMP15, GDF9, BMPR1A, MPR1B, BMPR2 and TGFBR1 mRNA expression in the oocyte, granulosa and theca cells of developing preovulatory follicles in the pig. Reproduction 2009, 138: 115-129.

8. Stankiewicz T, Błaszczyk B, Udała J: Selected aspects of pig oocytes maturation in vivo and in vitro. Med Weter 2008, 64: 400-403 (in polish).

9. Paulini F, Melo EO: The Role of Oocyte-Secreted Factors GDF9 and BMP15 in Follicular Development and Oogenesis. Reprod Dom Anim 2011, 46: 354-361.

10. Ebbert W, Bostedt H: Cystic Degeneration in porcine ovaries - first communication: morphology of cystic ovaries, interpretation of the results. Reprod Dom Anim 1993, 28: 441-450.

11. Fitko RJ, Kucharski B, Szlezyngier B, Jana B: The concentration of GnRH in hypothalamus, $\mathrm{LH}$ and FSH in pituitary, LH, PRL and sex steroids in peripheral and ovarian venous plasma of hypo- and hyperthyroid, cysts-bearing gilts. Anim Reprod Sci 1996, 45: 123-138.

12. Castagna CD, Peixoto CH, Bortolozzo FP, Wentz I, Neto GB, Ruschel F: Ovarian cysts and their consequences on the reproductive performance of swine herds. Anim Reprod Sci 2004, 81: 115-123.

13. Cech S, Dolezel R: Treatment of ovarian cysts in sows - a field trial. Vet Med-Czech 2007, 52, 413-418.

14. Tummaruk P, Kesdangsakonwut S: Factors affecting the incidence of cystic ovaries in replacement gilts. Comp Clin Path 2012, 21: 1-7.

15. Ebbert WF, Elsaesser F, Bostedt H: Cystic Degeneration in Porcine Ovaries - Second Communication: Concentrations of Progesterone, Estradiol-17 $\beta$, and Testosterone in Cystic Fluid and Plasma; Interpretation of the Results. Reprod Dom Anim 1993, 28: 451- 
463.

16. Safran A, Reubinoff BE, Porat-Katz A, Werner M, Friedler S, Lewin A: Intracytoplasmic sperm injection allows fertilization and development of a chromosomally balanced embryo from a binoovular zona pellucida. Hum Reprod 1998, 13: 2575-2578.

17. Payan-Carreira R, Pires MA: Multioocyte follicles in domestic dogs: a survey of frequency of occurrence. Theriogenology 2008, 69: 977-982.

18. Stankiewicz T, Błaszczyk B, Udała J: A Study on the Occurrence of Polyovular Follicles in Porcine Ovaries with Particular Reference to Intrafollicular Hormone Concentrations, Quality of Oocytes and their in vitro Fertilization. Anat Histol Embryol 2009, 38: 233-239.

19. Hunter MG, Robinson RS, Mann GE, Webb R: Endocrine and paracrine control of follicular development and ovulation rate in farm species. Anim Reprod Sci 2004, 82-83: 461-477.

20. Fouladi-Nashta AA, Waddington D, Campbell KHS: Maintenance of bovine oocytes in meiotic arrest and subsequent development in vitro: a comparative evaluation of antral follicle culture with other methods. Biol Reprod 1998, 59: 255-262.

21. Eppig JJ: Oocyte control of ovarian follicular development and function in mammals. Reproduction 2001, 122: 829-838.

22. Otsuka F, Mctavish KJ, Shimasaki S: Integral Role of GDF-9 and BMP-15 in Ovarian Function. Mol Reprod Dev 2011, 78: 9-21.

23. Prochazka R, Nemcova L, Nagyova E, Kanka J: Expression of Growth Differentiation Factor 9 Messenger RNA in Porcine Growing and Preovulatory Ovarian Follicles. Biol Reprod 2004, 71: 1290-1295.

24. Sun YL, Zhang J, Ping ZG, Wang CQ, Sun YF, Chen L, Li XY, Li CJ, Zhu XL, Liu Z, Zhang W, Zhou X: Relationship Between Apoptosis and Proliferation in Granulosa and Theca Cells of Cystic Follicles in Sows. Reprod Dom Anim 2012, 47: 601-608.

25. Błaszczyk B, Udała J, Gączarzewicz D: Apoptosis in the atresia of ovarian follicles. Med Weter 2000, 56: 158-163 (in polish).

26. Orisaka M, Orisaka S, Jiang JY, Craig J, Wang Y, Kotsuji F, Tsang BK: Growth differentiation factor 9 is antiapoptotic during follicular development from preantral to early antral stage. Mol Endocrinol 2006, 20: 2456-2468.

27. Hu CL, Cowan RG, Harman RM, Quirk SM: Cell cycle progression and activation of Akt kinase are required for insulin-like growth factor I-mediated suppression of apoptosis in granulosa cells. Mol Endocrinol 2004, 18: 326-338.

28. Craig J, Orisaka M, Wang H, Orisaka S, Thompson W, Zhu C, Kotsuji F, Tsang BK: Gonadotropin and intra-ovarian signals regulating follicle development and atresia: the delicate balance between life and death. Front Biosci 2007, 12: 3628-3639.

29. Solovyeva EV, Hayashi M, Margi K, Barkats C, Klein C, Amsterdam A, Hsueh AJ Tsafriri A: Growth Differentiation Factor-9 Stimulates Rat Theca-Interstitial Cell Androgen Biosynthesis. Biol Reprod 2000, 63: 1214-1218.

30. Pache TD, Chadha S, Gooren LJ, Hop WC, Jaarsma KW, Dommerholt HB, Fauser BC: Ovarian morphology in long-term androgen-treated female to male transsexuals. A human model for the study of polycystic ovarian syndrome? Histopathology 1991, 19: 445-452.

31. Galloway SM, McNatty KP, Cambridge LM, Laitinen MPE, Juengel JL, Jokiranta S, McLaren RJ, Luiro K, Dodds KG, Montgomery GW, Beattie AE, Davis GH, Ritvos O: Mutations in an oocyte-derived growth factor gene (BMP15) cause increased ovulation rate and infertility 
in a dosage-sensitive manner. Nat Genet 2000, 25: 279-283.

32. Hanrahan JP, Gregan SM, Mulsant P, Mullen M, Davis GH, Powell R, Galloway SM: Mutations in the genes for oocyte-derived growth factors GDF9 and BMP15 are associated with both increased ovulation rate and sterility in Cambridge and Belclare sheep (Ovis aries). Biol Reprod 2004, 70: 900-909.

33. Vireque AA, Reis RM, Rosa e Silva AAM, Resende LOT, Ferreira EM, Rosa e Silva ACJS, Ferriani RA: Involvement of Bone Morphogenetic Proteins (BMPs) in Ovarian Function and Infertility. Open Reprod Sci J 2008, 1: 11-15.

\title{
KONCENTRACIJE KOŠTANOG MORFOGENOG PROTEINA-15 (BMP- 15) I FAKTORA DIFERENCIJACIJE RASTA-9 (GDF-9) U FOLIKULARNIM CISTAMA, MONO I POLIOVOCITNIM FOLIKULIMA NAZIMICA
}

\author{
STANKIEWICZ Tomasz, BLASZCZYK Barbara
}

Cilj studije je bio da se odredi koncentracija BMP-15 i GDF-9 u tečnosti folikularnih cista i folikula ovarijuma kao i da se uporede njihove koncentracije kod mono i poliovocitnih folikula kod nazimica.

Studija je obuhvatala dva eksperimenta koji su obavljeni na ovarijumima sakupljenim na liniji klanja od nazimica (starosti 7-8 meseci). Prvi eksperiment je obuhvatao ispitivanje 31 nazimice sa po jednom folikularnom cistom (15-25 mm u prečniku) i 45 nazimica bez cista. Sakupljene su i analizirane folikularne tečnosti iz folikula prečnika 8-10 mm $(n=41)$ i 5-8 mm u prečniku $(n=41)$ kao i tečnost cista $(n=31)$. Drugi eksperiment je uključivao sakupljanje folikularne tečnosti od poli $(n=19)$ i od monoovocitnih $(n=22)$ folikula. Koncentracije BMP-15 i GDF-9 su određivane u uzorcima tečnosti korišćenjem ELISA kitova specifičnih za vrstu. Razlike u koncentracijama ovih faktora su izračunavane pomoću analize varijanse i posthok testom. U cilju određivanja statističke značajnosti razlika, upotrebljen je Duncan-ov višestrani test i to za $\mathrm{P}<0,05$ i $\mathrm{P}<0,01$. Korelacije između navedenih faktora su takođe izračunavane. Koncentracije BMP-15 i GDF-9 u tečnostima cista su bile značajno veće u odnosu na one u folikularnoj tečnosti $(\mathrm{P}<0,01)$. Međutim, nije ustanovljena razlika između folikula različitih veličina kao i između mono i poliovocitnih folikula.

BMP-15 i GDF-9 koncentracije su bile u pozitivnoj korelaciji ( $\mathrm{P}<0,01)$. Razlike u BMP15 i GDF-9 koncentracijama u folikulima ovarijuma i folikularnim cistama, kako je to prikazano studijom, ukazuju da ovi faktori mogu biti povezani sa poremećajima folikulogeneze kod nazimica. Štaviše, broj ovocita u folikulima ovarijuma ne utiče na intrafolikularnu koncentraciju BMP-15 i GDF-9. 